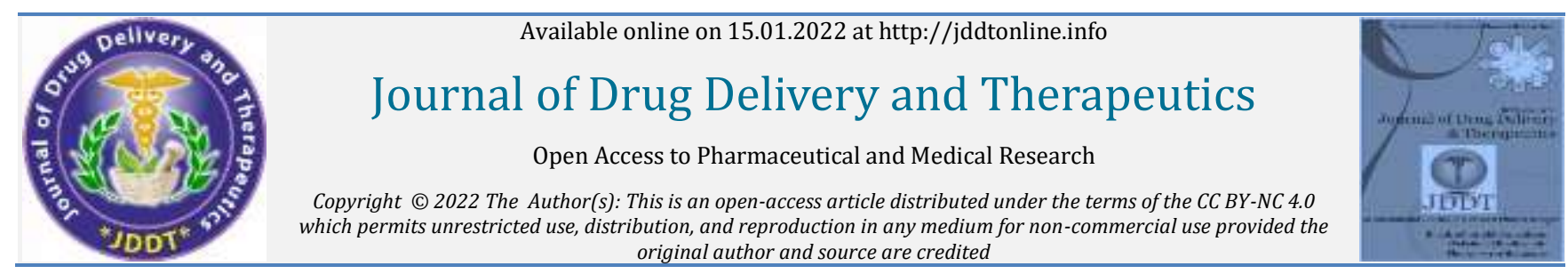

Open Access Full Text Article original author and source are credited

\title{
Child Immunization: Knowledge among Mothers in a North Karnataka Hospital
}

\author{
Nimmy N Johnn ${ }^{1 *}$, N Stanley John ${ }^{2}$, Midhunya JV ${ }^{3}$, H. Doddayya ${ }^{3}$ \\ ${ }^{1}$ Associate Professor, DM WIMS College of Pharmacy, Meppadi, Wayanad, Kerala, India \\ ${ }^{2}$ Research Associate, Office of Dr. S. S. Lal, Head of Public Health, Global Institute of Public Health, Trivandrum, Kerala \\ ${ }^{3}$ N.E.T Pharmacy College, Navodaya Nagar, Raichur, Karnataka, India
}

\begin{tabular}{ll}
\hline Article Info: & \\
& Article History: \\
& Received 11 November 2021 \\
& Reviewed 14 December 2021 \\
& Accepted 20 December 2021
\end{tabular}

\section{Cite this article as:}

John NN, John NS, JV M, Doddayya H, Child Immunization: Knowledge among Mothers in a North Karnataka Hospital, Journal of Drug Delivery and Therapeutics. 2022; 12(1):3335

DOI: http://dx.doi.org/10.22270/jddt.v12i1.5170

\author{
*Address for Correspondence: \\ Nimmy N jattumkalayil John, Associate Professor, DM WIMS \\ College of Pharmacy, Meppadi, Wayanad, Kerala, India
}

\section{Abstract}

Aim of the study: Immunization can be considered as a boon to the human kind as it helps to eradicate diseases. It has contributed to curtailing the mortality of children under-5 years in India. Giving awareness to the parents is the first and foremost factor to achieve the goal.

Methods and Materials: This study is carried out for a period of 8 months at Navodaya Medical College Hospital \& Research Centre, Raichur on the title "Knowledge of Mothers about the Children Immunization Status in Pediatric Inpatient and Outpatient Department" and the sample size was 2000 mothers who have visited department of paediatric with their children.

Result: It was observed that only $60 \%$ of the mothers were having knowledge about BCG, Hep A, Hep B, DTP and Polio. Although it is a fairly good knowledge score, the mothers were not informed about the need, dosing schedule of many vaccines.

Conclusion: Our study concluded that the extent of knowledge, attitude and practice of parents about child vaccination is very important. This study reflects that the majority of the respondents were having only partial knowledge about vaccination. The reason could be poor education and low awareness about immunization and vaccines in rural areas.

Keywords: Immunization, vaccine, awareness, paediatric.

\section{INTRODUCTION}

Vaccine produces immunity against a particular disease. Vaccination is considered to be the most cost effective means to prevent diseases from bacteria and viruses. Immunization curtails the morbidity and mortality rate to a greater extent 1 But according to the estimates, 25 million children and 50 million pregnant women are not receiving routine immunizations thereby almost 2 million people worldwide are dying from vaccine preventable diseases like rubella, tetanus, mumps, diphtheria, pertussis and poliomyelitis 2,3 .

A study conducted in Australia gave clear evidence of harmful and terrific events occurring because of the negligence of immunization. The pregnant women infected with German measles or Rubella virus delivered infants with deaf and dumb. Another study conducted in the United Kingdom showed that pregnant mothers infected with rubella virus gave birth to infants with congenital rubella syndrome ${ }^{4}$. Measles causes swelling of the brain, mumps can cause permanent deafness whereas meningitis leads to brain damage and polio to paralysis permanently. Refusing the immunization causes risks to the health of the child as well as other people around. Such harmful impacts are observed in people who are immune-compromised, newborns, elderly people with comorbidities. A high immunization rate will make our community free from vaccine preventable diseases. When parents choose to immunize their children, the community is free from the spread of infection.

The vaccines are boon to the man kind, as immunization has curtailed the mortality of children under 5 year old from 220 to $\sim 60$ per 1000 in the last five decades in India. But there are ample reasons where parents choose not to vaccinate their children. Studies show that safety concerns, fear of parents, religious beliefs and personal beliefs are few reasons for that. Thus a subset of parents either refuse to do or delay the vaccination of their children for various reasons 5,6 .

However there are no awareness programs available for the public in this regard. Healthcare workers have a major role in creating awareness to the public by circulating pamphlets regarding the age, dosing schedule etc.

\section{METHODS AND MATERIALS}

The study was carried out for a period of 9 months at Navodaya Medical College Hospital \& Research Centre, 
Raichur where the study design was prospective crosssectional study, and the sample size was 2000 mothers who have visited inpatient and outpatient departments of paediatric with their children. Data was collected using pre pre-designed questionnaire. Mothers who were willing to respond to questionnaires were included in the study. Whereas the participants who couldn't understand the content of the questionnaire after it had been explained to them and who were not willing to participate in the study were excluded.

\section{Data Management}

A cross-sectional study was carried out in order to assess the knowledge of mothers about the child immunization status. It was a face to face interview, in which the respondent's socio-demographics data, closed ended questions and open ended questions were included. Informed consent was taken from mothers who were willing to participate in the study. No attempt was made to correct the wrong answers.

The filled questionnaires were monitored for following variables:

- Education

- Family income

- Occupation

- Name and Schedule of Vaccine

\section{Statistical Analysis}

SPSS version 10.0 was used for data analysis and Chi-Square test used to represent the association between variables. The ' $\mathrm{P}$ ' value of $<0.05$ was considered significant. Microsoft Word and Excel were used to generate graphs, tables etc.

\section{RESULT}

TABLE - 1

\begin{tabular}{|l|l|l|}
\hline \multicolumn{1}{|c|}{ Age } & & Range \\
\hline Number of children & $21-25$ & 1040 \\
\hline & 840 & 2 \\
\hline Education of mother & Frequency & $\%$ \\
\hline Illiterate & & \\
\hline Primary and middle & 1180 & 59 \\
\hline High school and 12th & 620 & 31 \\
\hline Graduate or more & 160 & 8 \\
\hline Occupation of mother & 40 & 2 \\
\hline House wife & & \\
\hline Working & 1960 & 98 \\
\hline $\begin{array}{l}\text { Do you regularly immunize your } \\
\text { children }\end{array}$ & 40 & 2 \\
\hline Yes & & \\
\hline No & 590 & 29.5 \\
\hline Partially & 50 & 2.5 \\
\hline Immunization status & 1360 & 68 \\
\hline No vaccination & & \\
\hline Partial vaccination & 50 & 2.5 \\
\hline Full vaccination & 1360 & 68 \\
\hline Reason for partial vaccination & 590 & 29.5 \\
\hline Low awareness & 860 & \\
\hline Costly vaccines & 0 & 60.9 \\
\hline Wrong beliefs & 0 & 0 \\
\hline Less education & 550 & 0 \\
\hline $\begin{array}{l}\text { Child suffer disease due to lack } \\
\text { of immunization }\end{array}$ & & 39.1 \\
\hline Partially immunized & 0 & \\
\hline Not immunized & 0 & 0 \\
\hline Name of vaccine and schedule & & 0 \\
\hline Not aware & 1510 & 75.5 \\
\hline Partially aware & 450 & 22.5 \\
\hline Completely aware & 40 & 2 \\
\hline & & \\
\hline & & \\
\hline & & \\
\hline & & \\
\hline
\end{tabular}

\begin{tabular}{|l|l|l|}
\hline \multicolumn{1}{|c|}{ Age } & & Range \\
\hline Type of disease & $21-25$ & 1040 \\
\hline Measles & & \\
\hline TB & 0 & 0 \\
\hline Polio & 0 & 0 \\
\hline Hepatitis & 0 & 0 \\
\hline None & 0 & 0 \\
\hline $\begin{array}{l}\text { Name six common diseases of } \\
\text { children }\end{array}$ & 2000 & 2000 \\
\hline None & & \\
\hline Two & 1520 & 76 \\
\hline Three & 230 & 11.5 \\
\hline Four & 130 & 6.5 \\
\hline Six & 80 & 4 \\
\hline BCG Scar & 40 & 2 \\
\hline Yes & & \\
\hline No & 1970 & 98.5 \\
\hline Do you immunize your children? & 30 & 1.5 \\
\hline BCG & 1990 & \\
\hline Hep A & 880 & 49.5 \\
\hline Hep B & 1270 & 63.5 \\
\hline Polio & 1910 & 95.5 \\
\hline DTP & 670 & 33.5 \\
\hline Hib & 310 & 15.5 \\
\hline PCV & 500 & 25 \\
\hline RV & 360 & 18 \\
\hline Typhoid & 410 & 20.5 \\
\hline MMR & 710 & 35.5 \\
\hline Varicella & 320 & 16 \\
\hline Typhus & 300 & 15 \\
\hline & & \\
\hline & & \\
\hline & & \\
\hline
\end{tabular}

\section{DISCUSSION}

In the present study, it was observed that the education of mothers had a significant impact on the immunization of children. Mothers who were educated have shown better awareness about immunization of children. In the present study, among the 2000 mothers who were interviewed, only $41.5 \%$ were literate and $58.5 \%$ were illiterate. Out of them,

620 mothers $(31 \%)$ were educated till primary and middle school, 160 mothers (8\%) were educated till high school and $12^{\text {th }}$ and only $2 \%$ have acquired graduation. The mean age of the mother in the range of 21+_5. Most of them were having 2 children and were housewives.

In the present study, even though the government is providing many basic vaccines free of cost, children are not 
fully immunized with these vaccines. More awareness and education are needed for the respondents. Full immunization coverage was received by 590 children (29.5\%), partial immunization was received by 1360 children (68\%).

In this study low awareness about vaccination was the main barrier $(60.9 \%)$. Jayant et al in his study reported that the cost of vaccines is the main barrier for full immunization. Another study by Adil et al showed that the barriers for vaccination are cost and low awareness about the ill effects of non-vaccinating their children.1,2.

In our study few mothers (2\%) were aware about the name and schedule of vaccines. Most of the mothers (75.5\%) are not aware about the name and schedule of the vaccine. But fortunately, none of the children have any diseases due to lack of immunization.

In the present study, 1990 children(99.5\%) are immunized with BCG, 880 children (44\%) are immunized with Hep A, 1270 children $(63.5 \%)$ are immunized with Hep B, 1910 children $(95.5 \%)$ are immunized with polio, 670 children $(33.5 \%)$ are immunized with DTP, 310 children (15.5\%) are immunized with Hib, 500 children (25\%) are immunized with PCV, 360 children (18\%) are immunized with RV, 410 children $(20.5 \%)$ are immunized with typhoid, 710 children $(35.5 \%)$ are immunized with MMR, 320 children $(16 \%)$ are immunized with varicella and 300 children $(15 \%)$ are immunized with typhus.

\section{CONCLUSION}

Our study concluded that the extent of knowledge, attitude and practice of parents about childhood vaccination is very important. Here the study reflects that the majority of the respondents were having only partial knowledge about vaccination. The reason for this could be for poor education and low awareness about immunization and vaccines in rural areas.

It was observed that only $60 \%$ of the mothers were having knowledge about BCG, Hep A, Hep B, DTP and Polio. Whereas awareness about Hib, PCV, RV, Typhoid, MMR, Varicella, Typhus were below $20 \%$. Though this study gives a clear picture of knowledge of mothers about immunization in rural parts of our country. We could not take a step to assure that any awareness programs to be organized regarding immunization. The study reflects the idea that knowledge molds attitude and attitude drives proper practice. Hence a comprehensive plan to improve immunization coverage should work upon the rural and urban areas of north Karnataka.

\section{REFERENCES}

1 Upadhye JV, Marathe SM, Mandlik MR, Upadhye AJ, Upadhye JJ. Awareness and practices of parents about immunization of children in the age group 2-5 years. Int J Contemp Pediatr 2018; 5(5):1909-13. https://doi.org/10.18203/23493291.ijcp20183529

2 Trushitkumar P, Pathak R, Singh R, Alves V, Mahesh NM, Chaluvaraj TS et al. Assessment of Parents' Knowledge, Attitude and Practice about Child Vaccination in Rural areas. Journal of Pharmaceutical Research 2017; 16(3):229-36. https://doi.org/10.18579/jpcrkc/2017/16/3/118764

3 Adil MM, Zubair M, Alam AY, Khan SM, Ishtiaque ZB, Qureshi AA. Knowledge of mother's about children immunization status in the urban areas of Islamabad. Rawal Med J 2009; 34:1-9.

4 Ahmed SM, Rahman TAA, Masoed ES. Mothers' awareness and knowledge of under five years old children regarding immunization in Minia city Egypt. Life Sci J 2013; 10(4):122432.

5 Bhuiya A, Bhuiya I, Chowdhury M. Factors associating acceptance of immunization among children in rural Bangladesh. Health Policy Plan, 1995; 10:304-311. https://doi.org/10.1093/heapol/10.3.304

6. Borooah V. Gender bias among children in India in their diet and immunization against disease. Social Science and Medicine, 2004; 58:1719-1731. https://doi.org/10.1016/S02779536(03)00342-3

7. Deady J, Thornton L. Parents' knowledge of and attitude towards the primary childhood immunizations. Ir Med J 2005; 98:7-8

8. Guo WS, Zhang YY, Kang K, Diao LQ, Feng DX, Zhao S. Study Authenticity of parents' memory on their children's immunization status. Zhonghua Liu Xing Bing Xue Za Zhi. 2004; 25:229-31.

9. Shaikh S. Immunization status and reasons for vaccination in children, attending O.P.D. at Liaquat University Hospital. Pak Ped J 2003; 27:81-86.

10. Anjum Q, Omair A, Bazmi Inam SN, Ahmed Y, Usman Y, Shaikh S. Improving vaccination status of children under five through health education. J Pak Med Assoc 2004; 54:610-3. 